FACTA UNIVERSITATIS

Series: Teaching, Learning and Teacher Education Vol. 4, № 2, 2020, pp. $101-112$

https://doi.org/10.22190/FUTLTE2002101J

Original research paper

\title{
EDUCATIONAL ASPECTS OF ADULT PARTICIPATION IN PLAYFUL ACTIVITIES
}

\author{
UDC 374.7:793/794; 159.922.6:79; 371.382:374
}

\section{Dragana Jovanović}

Faculty of Philosophy, Department for Pedagogy, University of Niš, Serbia

\begin{abstract}
Playfulness in adulthood has been shown to be un-researched scientific issue. We believe that it is because of earlier non-recognition of this issue as a special field of study, but also the existence of a popular belief that the playful activities are reserved only for children. Just because of the lack of initiative and coherent researches that take into account playful activities in adulthood and characteristic of playfulness as a personal trait this research can be considered as the first research of that kind in the Republic of Serbia. The aim of this research is to determine adult perceptions of their playfulness and dominant cognitive qualities of playfulness. Adult Playfulness Trait Scale was used (APTS) to explore adult playfulness and inherent cognitive characteristic of this personal trait. Research sample consists of 1234 adult individuals aged from 18 to above 60 years from a cities and villages of Serbian area. The results of this research show that respondents recognize and highly value all tree sub-dimensions of playfulness trait: fun-seeking motivation, uninhibitedness and spontaneity. An important finding of this research is one that indicates on the characteristics of fun-seeking motivation subdimension as dominant one.
\end{abstract}

Key words: playfulness, adulthood, fun-seeking motivation, uninhibitedness, spontaneity

\section{INTRODUCTION MAIN}

In various scientific research sources (Lieberman, 1977; Guitard et al., 2005; Barnett, 1991, 2007; Proyer, 2017), playfulness is seen as an individual's predisposition that provides him or her with the opportunity to connect with others, with circumstances and conventions, to approach situations with an open mind, think out of the box in order to find original solutions to various problems, to understand and overcome the difficulties encountered more easily, as well as to be able to face potential failures. This is a predisposition that allows an individual to become engaged, to create fun activities on his own and initiate

Received December 07, 2020/Accepted December 15, 2020

Corresponding author: Dragana Jovanović

Faculty of Philosophy, University of Niš, Ćirila i Metodija 2, 18000 Niš, Serbia

Phone: +381 18514312 •E-mail: dragana.jovanovic@filfak.ni.ac.rs 
interaction. Throughout history, national and international researchers have invested a lot of effort and valuable time in studying the play and various playful activities, but unfortunately all of them were mostly focused on childhood period. Generally speaking, most of these research endeavours have undoubtedly established that playful activities and behavior related to them, as well as playfulness itself, affect the general well-being and children's developmental path. Playfulness as a personality trait, and especially playfulness in adulthood, was not a topic that was covered in past studies. Perhaps the shortcomings of the initial, and especially more analytical research of adulthood playful activities in the past could be justified by the fact that this issue was not recognized as a special field of study. To this should be added the common opinion that the forms and mechanisms of play in childhood and adulthood can be very similar, but that play in adulthood is structurally and fundamentally different from children's play because of the assumptions, formed values and attitudes that become embedded into it, due to the identified acceptability and different forms of play and the way others appraise them. It could be said that playfulness in adulthood was quite stigmatized in the eyes of the academic community, characterized by prejudices and beliefs that it was reserved only for the childhood period, an incomprehensible topic for many and thus rejected as a subject of study. Certainly, it is clear that there is a lack of coherent research evidence for this topic, but luckily for the academic community and for the pedagogical, psychological and andragogical reality, the importance and need to instigate the first research initiatives in this direction was recognized. Thus, in the last few years, the research efforts of several authors (Bateson et al, 2013; Leung, 2014; Pinchover, 2017; Shen, 2010; Shen et al., 2014a, 2014b; Shen et al., 2017; Proyer, 2012, 2013, 2014, 2017, 2018; Yu et al., 2007; Yue et al., 2016) to focus more on this topic have come to the fore. The results of these studies indicate certain pedagogical and psychological aspects of playfulness and playful activities in adulthood, but also the effects they produce on the overall functioning of an adult individual in different areas of life and work. The educational assumptions presented in this paper, as well as the analysis of this issue from a pedagogical and psychological point of view, are based on the findings of a small number of available studies, and some are supported by the results of our own research. This study is a part of a pilot study within broader research project whose main focus is to examine the indicators and models of family and business roles (project 179002). More specifically, the aim of this research is to investigate the playfulness and cognitive characteristics of playfulness in adulthood, as well as to interpret the obtained data from a pedagogical and andragogical point of view.

\section{Playfulness IN ADULTHOOD - CONCEPTUALIZATION AND THEORETICAL BACKGROUND}

The term playfulness in adulthood has recently become present in the opus of generalizations of certain social sciences theorieticians, especially sociology, psychology, pedagogy, and certain andragogical initiatives to place adulthood playfulness in an educational context stand out as well. This becomes even more important when a more complete and comprehensive overview of the various aspects and roles of play on adult learning and functioning, both professionally and privately, is taken into account. And as it usually happens with new terms and phenomena, when interpreting, defining and operationalizing this term with regard to age, there are many problems, dilemmas, doubts, and most often controversies and "difficult to refute" points of view found in the literature 
which are difficult to deal with. The problem becomes even more delicate, and to some extent specific, if we take into account that in the available literature only recently some attempts can be seen to give this term more precise definitions, and to approach it from different theoretical perspectives. Certainly, opprtunities to understand this concept have been allowed thanks to published research papers of recent date in the field of psychology and andragogy, especially those published in the last twenty-thirty years. The impetus for such research seems to have arisen from conflicts among theoreticians in the the field of psychology. Namely, when studying playfulness as a personal trait through behaviors in the playful activities, the authors could not come to a single point of view on the issue of manifestation of heterogeneous behavior. This created a gap between them, where one side advocated the view of playful cognitive style and the other side the view of personal orientation that transcends situations and activities. This was precisely what motivated some authors to focus their research on the inner psychological qualities or attributes that make a person playful. From such and similar studies in other fields, it was concluded that playfulness extends and even intensifies as people age, although with qualitatively different characteristics and forms compared to childhood. Obvious differences in the playful behavior of adults and children were emphasized, in the sense that the predominant sensorimotor plays are increasingly changing towards social, imaginative and cognitive playful activities, and the expression of playfulness increasingly exceeds the boundary between leisure and work and is transferred to different life situations. In this regard, certain aspirations have been made to bring the concept of playfulness as close as possible to the academic community and other stakeholders.

In 2007, Barnett offered her own definition of this concept, guided by the shortcomings of earlier definitions. According to her, playfulness is "the predisposition to frame (or reframe) a situation in such a way as to provide oneself (and possibly others) with amusement, humor, and/or entertainment." (Barnett, 2007, p. 955). Like her, Proyer 10 years later, based on his extensive studies of this personality trait, gave a somewhat broader definition of playfulness: "Playfulness is an individual differences variable that allows people to frame or reframe everyday situations in a way such that they experience them as entertaining, and/or intellectually stimulating, and/or personally interesting. Those on the high end of this dimension seek and establish situations in which they can interact playfully with others (e.g., playful teasing, shared play activities) and they are capable of using their playfulness even under difficult situations to resolve tension (e.g., in social interactions, or in work type settings). Playfulness is also associated with a preference for complexity rather than simplicity and a preference for - and liking of - unusual activities, objects and topics, or individuals" (Proyer, 2017, p. 114). Shen and her associates (Shen et al., 2014a) defined playfulness in adulthood as a personal trait that underlies the individual's aspiration to be intrinsically motivated, with a clear orientation towards entertainment, and their own spontaneous engagement in a certain unrestrained, unforced manner. More specifically, these authors claim that the playfulness trait consists of three interconnected motivational and (no motivational) cognitive qualities: 1 . a strong fun-seeking motivation that drives the individual to actively derive fun from his or her internal and/or external environment; 2. uninhibitedness, an ability to subdue potentially constraining situational factors and create a free, uninhibited mental state; 3. spontaneity, a mental propensity to respond promptly without deep thought or premeditation. In general, we could agree with Barnett's (Barnett, 1991) statement that playfulness is defined as the tendency of an individual to engage in playful activities, as well as Lieberman's (1977) which is considered a personality trait that is 
expressed across situations and various parts of a person's life. Shen and associates (Shen et al., 2014a) define playfulness as a "personality trait that underlies the individual's tendency to be intrinsically motivated, with a clear fun orientation, and to engage oneself spontaneously in an unconstrained manner" (Shen et al., 2014a, p. 68). They indicate that playfulness trait consists of mutually interconnected motivational (or non-motivational) cognitive qualities: funseeking motivation, uninhibitedness and spontaneity. So, from the available literature and little number of research work, an effort can be noticed of some authors to give a clearer definition of adult playfulness.

Why adult playfulness has not been researched until recently? We could agree with the statement of Stojiljkovic and associates that "scientific interest in play as a social phenomenon emerged only in the eighteenth century. Until then, play was marginalized, considered unnecessary, that is, the activity of people who have no other business" (Stojiljković et al., 2019, p. 162). Playfulness can be most simply defined as engaging in some fun activity for pleasure or even recreation. The individuals with pronounced predispositions for playful activities and playfulness are characterized by specific behaviors and characteristics - they are fun, witty, spontaneous, unpredictable, impulsive, active, energetic, optimistic, adventurous, sociable, open, cheerful, and happy. It is likely that people with such qualities will show their playfulness and liveliness through teasing, joking or playing around, that is, foolish or childish behavior. Adults engage in playful activities for the sake of playing and spontaneously in order to initiate a feeling of comfort, a sense of engagement and satisfaction in it, and also to make an activity easier to bare, especially the one that can cause certain difficulties, pressure and discomfort. For adults, the act of the play itself is more important than its outcome. Unlike the playful activities of children which they use to learn about the "state of being" including empathy, communication with others and how to deal with victories and defeats in them, the adult playful activities are quite different. The types of children's resilient learning processes differ from those that occur in adults, but harmony is certainly established in adulthood as well. The adults initiate playful activities for various reasons, most often in order to build a kind of community, foster sharpness, but also keep the loved ones close to them. By combining playfulness with any activity that an individual engages it can certainly encourage his creativity, emotional well-being and ability to solve the problems he encounters in that activity.

\section{Adult PlayfulNess Versus ChILdREN PlayfulNESS - REVIEW OF SOME RESEARCheS}

Shen and her associates pointed out that there is a lack of consensus about the very conceptualization of adult playfulness, such as that of children's playfulness, due to the variety of related characteristics (Shen, 2010, Shen et al., 2014a). Namely, in order to come to a closer definition of playfulness in adulthood, these authors integrated certain achievements of personality research and playfulness research, creating the Adult Playfulness Trait Scale, which was refined into the final version after the focus group research (see Shen et al, 2014a, 2014b). An earlier study by Barnett (2007) clearly indicated the common qualities of playfulness in children and in adults. Namely, she mentioned spontaneity and cheerfulness as common descriptors of both populations, but also the impulsivity as the common component. On the other hand, it can be concluded from the study by Guitard et al. (2005) that adult playfulness is very similar to children's playfulness, because it mostly includes creativity, curiosity, and sense of humor, pleasure and spontaneity. Glynn and Webster (1992) indicate that expressiveness, fun, and playing 
around are components of adult playfulness rather than children's playfulness. Some studies have drawn attention to the fact that individuals who have the playfulness trait and who engage in play typical of adults are usually fun, unobtrusive, witty and casual, and most often under different situations and circumstances will use this "gift" to play, to make jokes and be jolly, to tease, make fun statements, but also engage in silly, childish actions. It is important to emphasize that more recent studies such as Proyer's (Proyer, 2012, 2013, 2014), Bateson et al. (Bateson et al., 2013), and Yue et al. (Yue et al., 2016) have suggested that playfulness in adults is connected with well-being, a sense of happiness, relationship satisfaction, a higher level of appreciation of wit and creativity.

When speaking about the work environment and the business context itself, it is indisputable that the research by $\mathrm{Yu}$ and his associates ( $\mathrm{Yu}$ et al., 2007) also made a valuable contribution to the study of the adult playfulness topic. These authors highlighted the positive relationship between playfulness and job satisfaction, and work performance as the main result of their research. A study conducted by Leung (2014) in a sample of respondents who were students in China and Guangdong showed positive correlation between adult playfulness, sense of humor, adaptive humor, importance of humor, selfreferential humor and subjective happiness. The results of this study confirmed earlier claims by various authors about the benefit of playfulness for psychological well-being.

Moreover, the studies conducted worldwide have clearly suggested that playfulness in adults should not be understood as a kind of fooling around or playing around (joking, clowning) but as an important tool or aid to reducing stress, contributing not only to social well-being but overall well-being of a person. Playful people are able to transform everyday situations, even stressful ones, into something fun for them. Barnett (Barnett, 2007) believes that people who are very playful and cheerful feel stress in the same intensity as everybody else, but experience it in a completely different way and react to it differently. This actually allows them to reject stressors more easily compared to people who have this playfulness trait in a much lesser extent.

Proyer's (2017) study of the complexity of playfulness in adults yielded four types of adult behavior: 1) those who truly enjoy joking with friends, colleagues, relatives and co-workers; 2) those who are generally cheerful and unconcerned about the future consequences of their behavior; 3) those who play with thoughts and ideas; 4) those who are capricious or moody, who are occupied with unusual and strange things, amuse themselves with small, everyday observations.

Another important category that some studies have covered should not be neglected, and that is the parent category. Namely, Shen et al. (2017) conducted a research with the aim of determining the connection between parents' playfulness and children's adaptive behavior. They found a positive correlation between playfulness with all aspects of adaptability, and that the playfulness of mothers (not fathers) was positively associated with the playfulness and adaptability of young adults. In order to highlight the connection between the playfulness of adults and children, the author Pinchover (2017) conducted a pilot study in a sample of teachers and students. This was one of the first studies to show that aspects of teacher playfulness are positively associated with higher levels of playfulness in children. More specifically, there were high correlation levels between spontaneity and silliness, i.e., between the childish behavior of teachers and playfulness in children.

Although playfulness is usually observed from the aspect of personal traits - playful behavior such as joking around and childish behavior of adults can also be considered skills that can be acquired, developed and improved, especially when it comes to the education 
context. Also, adult playfulness especially in teaching improves quality of interactions between teachers and pupils and between pupils themselves. Quality feedback through play activities of both sides is not only a condition of quality interaction but also developmental communication. So, as said Jovanović (2020) "since the continuous and good-quality feedback is the prerequisite of successful interaction in teaching, in order to ensure the proper quality of interaction, it is important to recognize and respect the feedback, regardless of whether it is verbal or non-verbal in nature" (p. 17). Above mentioned activities, including the spontaneity that accompanies them, and other playful behaviors used for pedagogical purposes are easier to manifest once the play-based self-assessment techniques and communication techniques have been mastered.

\section{Methodology}

This study was designed to investigate key sub-dimensions of adult playfulnes as a personal trait, i.e. cognitive qualities of playfulness. The study was also conducted to explore respodents' perceptions of their own playfulness and on the basis of obtained results, draw andragogical and pedagogical implications. Information on adults' playfulness and cognitive qualities of playfulness was collected through translated adapted Adult Playfulness Trait Scale - ATPS (Shen, Chick and Zinn, 2014a, 2014b). After obtaining the author's permission for the use, translation and adaptation of the instrument, it was adapted to the cultural and andragogical context and research needs, taking into account the more detailed instructions defined within the cooperation between author and researcher. The advantage of this questionnaire is that it occurs in a form of self-assessment in relation to the specific characteristics of adult playfulness behavior. Research participants answered a total of 19 items of the revised, validated and tested version of ATPS. Due to the economy and rationality of the questionnaire, and for the purposes of adaptation to our educational context as well as standard procedure we changed 7-point scale assessment to 5-point scale assessment. All items are organized to measure 3 sub-dimensions (cognitive cognitive qualities) of playfulness: (1) a strong fun-seeking motivation that drives the individual to actively derive fun from his or her internal and/or external environment ( 9 items), (2) uninhibitedness, an ability to subdue potentially constraining situational factors and create a free, uninhibited mental state (5 items) and (c) spontaneity, a mental propensity to respond promptly without deep thought or premeditation ( 5 items). The study was conducted by the end of 2018 and in the beginning of 2019 year.

The research sample consisted of a total of 1258 respondents from urban and rural areas in the Republic of Serbia. The final analysis framework included only correctly completed questionnaires. Since not all respondents answered all the questions, which were mainly focused on the description of the sample structure, the tables below show mixed data based on their answers. The research sample included respondents of both genders, different levels of education and profession. The minimum age of the respondents at the time the research was conducted was 18 years of age (born in 2000), and the maximum age was 61 (born in 1939). The sample structure is shown based on: (1) gender (Table 1), (2) age (Table 2), (3) level of education (Table 3), (4) place of residence (Table 4). 
Table 1 Sample structure according to gender of respondents

\begin{tabular}{lcc}
\hline Gender & Frequency & Percent \\
\hline Male & 440 & 35.0 \\
Female & 794 & 63.1 \\
\hline Total & 1234 & 98.5 \\
\hline
\end{tabular}

The table showing the gender structure of the respondents clearly indicates that the percentage of male and female respondents is not even approximately equal. The respondents who answered this question (out of the total sample of 1258, 1234 of them answered it) are mostly female respondents, i.e. there were almost twice as many female respondents than male respondents $(63.1 \%$ vs. $35.0 \%)$.

Table 2 Sample structure according to age

\begin{tabular}{lcc}
\hline Age & Frequency & Percent \\
\hline Up to 30 & 917 & 72.9 \\
$31-40$ & 254 & 20.2 \\
$41-50$ & 47 & 3.7 \\
$51-60$ & 9 & 0.7 \\
Above 60 & 2 & 0.2 \\
\hline Total & $\mathrm{N}=1234$ & 98.1 \\
\hline
\end{tabular}

In order to obtain data on the age structure of the sample, categories were formed based on the respondents' year of birth: (1) up to 30 years of age - respondents born between 1971 and 2000, (2) 31-40 years - respondents born between 1961 and 1970, (3) 41-50 respondents born between 1951 and 1960, (4) 51-60 - those born between 1941 and 1950, and (5) over 60 years of age - the remaining respondents born between 1931 and 1940. As it can be seen from the table above, the highest percentage of respondents $(92 \%)$ who answered this question (1234 out of a total of 1258) are young adults aged 18 to 40, and the lowest percentage $(4.6 \%)$ are those who are middle-aged and elderly.

Table 3 Sample structure according to educational level of respondents

\begin{tabular}{lcr}
\hline Educational level & Frequency & Percent \\
\hline Unfinished elementary school & 2 & 0.2 \\
Elementary school & 34 & 2.7 \\
Secondary school & 548 & 43.6 \\
High school & 190 & 15.1 \\
BA degree or MA degree & 448 & 35.6 \\
PhD & 8 & 0.6 \\
\hline Total & 1230 & 97.8 \\
\hline
\end{tabular}

In regards to the respondents' level of education, it can be noticed that the sample of respondents mostly includes the respondents with the level III and IV of education $(43.6 \%)$ and those with the VII/1 and VII/2 level of education $(35.6 \%)$ - the percentage of respondents with VI and VIII education level is lower. The lowest percentage is of those with complete or incomplete basic education, i.e. I and II education level. 
Table 4 Sample structure according to respondents' living place

\begin{tabular}{lcr}
\hline Living place & Frequency & Percent \\
\hline City & 1073 & 85.3 \\
Village & 176 & 14.0 \\
\hline Total & 1249 & 99.3 \\
\hline
\end{tabular}

As already mentioned, the sample consisted of respondents from different regions in the Republic of Serbia. For the sake of efficiency and for the purposes of this paper, they are divided into two categories based on the type of settlement, i.e. the respondents who live in the city and those who live in the village. These categories of settlements and the data relating to them indicate that the highest percentage of the total sample are respondents from urban areas $(85.3 \%)$, while almost one sixth of the sample are respondents living in rural areas $(14.0 \%)$.

Table 5 Descriptive indicators of APTS scale

\begin{tabular}{lccccc}
\hline Qualities of adult playfulness & $\mathrm{N}$ & Min. & Max. & Mean & Std.deviation \\
\hline Unsubordinativeness & 1247 & 1 & 5 & 3.01 & 1.282 \\
Reactiveness & 1245 & 1 & 5 & 3.80 & 1.084 \\
Levity & 1245 & 1 & 5 & 3.09 & 1.301 \\
Endavour_Initiative & 1247 & 1 & 5 & 3.45 & 1.240 \\
Unpredictability & 1239 & 1 & 5 & 2.81 & 1.339 \\
Resourcefulness_Initiative & 1241 & 1 & 5 & 3.54 & 1.104 \\
Respectfulness & 1231 & 1 & 5 & 4.02 & 0.987 \\
Directness & 1247 & 1 & 5 & 3.13 & 1.303 \\
Willingness & 1241 & 1 & 5 & 3.58 & 1.164 \\
Fun Belief & 1247 & 1 & 5 & 3.95 & 1.038 \\
Impulsiveness & 1244 & 1 & 5 & 2.98 & 1.330 \\
Unrestraint & 1239 & 1 & 5 & 3.11 & 1.234 \\
Activism Initiative & 1237 & 1 & 5 & 3.28 & 1.223 \\
Coziness_Reactivity & 1241 & 1 & 5 & 3.78 & 1.067 \\
Thoughtfulness & 1242 & 1 & 5 & 3.54 & 1.109 \\
Sensitiveness & 1230 & 1 & 5 & 3.66 & 1.074 \\
Confidence_Fun_Belief & 1245 & 1 & 5 & 3.07 & 1.000 \\
Silliness & 1204 & 1 & 5 & 4.01 & 1.033 \\
Capability & 1226 & 1 & 5 & 3.51 & 1.076 \\
\hline
\end{tabular}

All qualities of adult playfulness are well assessed because they have an average value above 3. Only the data that can be observed in the statements related to certain characteristics of spontaneity go beyond the limits of interpretation (higher degree of agreement $\bar{x}>3$ and lower degree of agreement $\bar{x}<3$ ) like as unpredictability and impulsiveness. However, the values of the standard deviation indicate that the data are above expectations and as such interpretable. Thus, by calculating the arithmetic means, it was found that the respondents had a greater tendency to agree with the items related to fun-seeking motivation as a quality of adult playfulness like as respectfulness, fun-belief, reactiveness, coziness, and quality uninhibitedness (silliness). Regarding the choice of items to which the respondents had less inclination, i.e. as less important characteristics, they singled out some related to spontaneity (sensitiveness and thoughtfulness), as like as some characteristic of uninhibitedness (willingness), and again fun-seeking motivation 
(resourcefulness). On some items which indicate on characteristic of fun-seeking motivation like as capability, endeavor, activism and confidence respondents rated as a lower degree of agreement, as well as directness which belong to spontaneity, and unrestraint and levity as the characteristics of uninhibitedness. Finally, smallest tendency of respondents agreement was shown in the statements related to spontaneity as mentioned on the beginning of this paragraph (unpredictability and impulsiveness).

The Adult Playfulness Scale consists of 19 items on the basis of which data on the cognitive qualities of adult playfulness (fun-seeking motivation, uninhibitedness and spontaneity) could be obtained. In order to test the hypothesis of a dominant subdimension, three new variables of global indicators of adult playful activities were formed. The newly formed variables were obtained by summing the variables of lower order, i.e. by summing the variables of the sub-dimensions of adult playfulness.

Fun-seeking motivation was obtained by calculating the sum of variables (which we have abbreviated for the sake of economy and for the purposes of this paper): reactiveness, endeavor, resourcefulness, respectfulness, fun-belief, activism, coziness, confidence and capability. The variable uninhibitedness of adult playfulness was created in the same way by taking into account the variables: unsubordinativeness, levity, willingness, silliness, and unrestraint. Finally, the spontaneity of adult playfulness is the result of a sum of variables: unpredictability, directness, impulsiveness, thoughtfulness, sensitiveness. After the formation of new variables, the normality of the distribution of them was examined by Kolmogorov-Smirnov test. The obtained data are presented in below table.

Table 6 Test of normality of variables distribution

\begin{tabular}{lcccccc}
\hline & \multicolumn{2}{c}{ Kolmogorov-Smirnov } & & \multicolumn{3}{c}{ Shapiro-Wilk } \\
\cline { 2 - 7 } & Static & df & Sig. & Static & df & Sig. \\
\hline Fun-seeking motivation & 0.65 & 1254 & 0.000 & 0.986 & 1254 & 0.000 \\
Uninhibitedness & 0.59 & 1254 & 0.000 & 0.989 & 1254 & 0.000 \\
Spontaneity & 0.59 & 1254 & 0.000 & 0.989 & 1254 & 0.000 \\
\hline
\end{tabular}

Based on the results shown in the table 6, it can be noticed that the empirical distribution of data deviates statistically significantly from the normal distribution in examined sample. Since the preconditions for the application of parametric tests were not met, for the purpose of comparison, a nonparametric test was applied, more specifically the Friedman test for dependent samples. Given that the essence of this test is in the ranking of data, we compare the mean values of the ranks for all respondents with the expected, and it is assumed that the most common is fun-seeking motivation. Whether the obtained rankings support this assumption or not is indicated by the data of the Friedman test shown in the Table 7.

Table 7 Representation of cognitive qualities of adult playfulness

\begin{tabular}{lcccc}
\hline Cognitive qualities & Mean ranks & $\mathrm{p}$ & Mean & Std. deviation \\
\hline Fun-seeking motivation & 2.99 & & 33.03 & 7.13 \\
Uninhibitedness & 1.58 & 0.000 & 16.53 & 4.05 \\
Spontaneity & 1.43 & & 15.93 & 4.41 \\
\hline
\end{tabular}

From the obtained data, statistically significant differences can be observed in terms of perceived qualities of adult playfulness. Namely, the respondents included in the research 
perceived the sub-dimension of fun-seeking motivation as dominant in relation to uninhibitedness and spontaneity. Mean rank values indicate the highest representation of the fun-seeking motivation sub-dimension and the lowest representation of the spontaneity sub-dimension. Although according to the respondents' perception, spontaneity proved to be the at least represented cognitive quality of their playful activities. The difference in values between spontaneity and uninhibitedness was not large. In both cases, the values of the average rank are close, which speaks in favor of the fact that spontaneity does not lag far behind uninhibitedness. More precisely, it could be stated that our respondents possess all three cognitive characteristics of playfulness which are interconnected, with the fact that they are more inclined to be actively involved in creating entertainment from their internal or external environment than to submit to limiting situational factors or to spontaneous, reckless reaction without prior reflections.

Generally speaking, especially having in mind the results from table 5 and table 7 we can conclude that these tree sub-dimensions represents driving forces of personality character. Our examinees like to follow and respect fun activity that initiates people in their own surroundings, they gladly get engaged in them, find enjoy and pleasance, and most importantly they believe in good fun. Through the play, laughter and jokes, by mutually participations in some playing activities (planed or unplanned) for fun, individuals brings joy, resilience and vitality to each other. Also, effects of playful activities of adults can reduce dissatisfaction, disagreements, and even certain negative phenomena like as communication conflicts between adults or adults and children. An orientation towards fun issues and motivation to engage, to seek and create interesting and silly situations may help each individual to improve quality of social interactions and communication. If we add to that same characteristics of uninhibitedness like as an individual's belief on the importance of playfulness in life and willingness to do something fun regardless of the opinions of others and their desire to prevent him/her from doing so, the value of playfulness gained even more necessity. In activities of this type, individuals are often guided by their current feelings and thoughts, which is somewhat supported by the results of this research within the sub-dimension of spontaneity. Through good play, we learn to gain trust in others and gain trust from others. This is undoubtedly the basis for developing a sense of security on both sides. Only a sense of trust provides opportunities for cooperation, establishing closer relationships and intimacy, as well as testing and learning new things, and maybe freedom to trying out "unfathomable" or unknown activities. It should not be forgotten the conscious effort of individuals to spice up mutual interactions with more wittiness and play, which certainly makes the quality of relationships that are built in a group, whether business or educational, or family, greatly improved. Adults use play to remove existing barriers and improve their relationships and connections with others in their environment. This can be especially pronounced in the teaching process when teacher apply wittiness, quips and pranks, and some kind of silly behavior in teaching. In such case learning process become more enjoyable, interesting, pleasant and increase self-motivation, reduce stress and anxiety when dealing with difficult tasks and teaching material. On the other hand, playful behavior helps to develop and improve social skills. In this regard, it is good to implement playful activities but to engage others in them and lead them to initiate them themselves. This unquestionable contributes to the creation of a common psychological, pedagogical and andragogical bond between teachers and students, but also among adults themselves. 


\section{CONCLUSIONS}

As it can be concluded from the above-mentioned, research on playfulness in adults is quite limited. In our region, there are almost no papers whose research was focused on adult playfulness. Perhaps the still present patriarchal upbringing model, in which the idea that play is reserved for children is deeply rooted, contributes to this. Nevertheless, after reviewing the international studies, perhaps this research could be classified as the first step taken that will allow the Serbian education system and context to understand the role and significance, the extent and limitations of adult play activities, although they differ significantly from children's play activities in their nature, characteristics and forms. This is precisely the value of adult playfulness, the effect it has on the overall work and functioning in society and one's surrounding.

It can be concluded from the research conducted:

(1) The surveyed adults highly estimated their playfulness activities in everyday life; they recognize importance and role of play and all characteristic of playfulness. It seems that all of respondent have, to a greater or lesser extent, a playfulness trait.

(2) Although in theoretical and research papers little space is devoted to playfulness as a personality trait, respondents perceive the cognitive qualities of their playfulness especially those which are key characteristic of fun-seeking motivation like as respectfulness, fun-belief, reactiveness, coziness, resourcefulness, capability, endeavor, activism and confidence.

Having in mind that this is just a part of our investigation, in the paper are represented initial results. Other results obtained by this research will be a subject of future papers. One can be concluded - although playfulness in adults remains an insufficiently researched field in the social sciences, primarily in psychology and andragogy, further studies are needed, especially in Serbia, in order to emphasize its significance and benefits.

\section{REFERENCES}

Barnett, L. (1991). Characterizing playfulness: Correlates with individual attributes and personality traits. Play and Culture, 4, 371-393.

Barnett, L. (2007). The nature of playfulness in young adults. Personality and Individual Differences, 43(4), 949958. https://doi.org/10.1016/j.paid.2007.02.018

Bateson, P., Pateson, G., \& Martin, P. (2013). Play, playfulness, creativity and innovation. Cambridge: Cambridge University Press.

Jovanović, M. (2020). Facial expressions in primary school teaching as the feedback in communiaction process. Facta Universittatis: Teaching, Learning and Teacher Education, 4(1), 17-26. https://doi.org/10.22190/ FUTLTE2001017J

Leung, R. (2014). Adult playfulness and its relationship to humor, subjective happines and depression: A comparative study in Hong Kong and Mainland China. Discovery - SS Student E-Journal, Vol. 3, 105-141. https://doi.org/10.1177/0033294116662842

Lieberman, J. N. (1977). Playfulness: Its relationship to imagination and creativity. New York, NY: Academic Press.

Glynn, M, \& Webester J. (1992). The adult playfulness scale: An initial assesment. Psychological Reports, 71, 81-83. http://dx.doi.org/10.2466/PR0.71.5.83-103

Guitard, P., Ferland, F., \& Dutil, É. (2005). Toward a better understanding of playfulness in adults. OTJR, 25(1), 9-22. https://doi.org/10.1177/153944920502500103

Stojiljković, N., Uzunović S., \& Stamenković, S. (2019). Playful forms of art - the application of dance in the teaching of physical education. Facta Universitatis: Teaching, Learning and Teacher Education, 3(2), 161169. https://doi.org/10.22190/FUTLTE1902161S

Pinchover, S. (2017). The relation between teachers' and children's playfulness: A pilot study. Frontiers in Psychology, 8:2214. https://doi.org/10.3389/fpsyg.2017.02214 
Shen, X. (2010). Adult playfulness as a personality trait: Its conceptualisation, measurement and relationship with spychological well-being (Doctoral dissertation). Pennsylvania State University Library Catalog.

Shen, X., Chick, G., \& Zinn, H. (2014a). Playfulness in adulthood as a personality trait: A reconceptualization and a new measurement. Journal of a Leisure Research, 46, 58-83.

Shen, X., Chick, G., \& Zinn, H. (2014b). Validating the Adult Playfulness Trait Scale (APTS): an examination of personality, behavioral, attitudional, and perceptual nomological network of playfulness. American Journal of Play, 6, 345-369.

Shen, X., Chick, G., \& Pitas, N. (2017). From playfull parents to adaptable children: a structural euation model of the relationship between playfulness and adaptibility among young adults and their parents. International Journal of Play, 6(3), 244-254. http://dx.doi.org/10.1080/21594937.2017.1382983

Proyer, R., Gander, F., Bartenshaw, E., \& Brauer, K. (2018). The positive relationship of playfulness with indicators of health, activity and physical fitness. Frontiers in Psychology, 9, 1440. https://doi.org/10.3389/ fpsyg.2018.01440

Proyer, R. (2017). A multidisciplinary perspective on adult play and playfullness. International Journal of Play, 6(3), 241-243. https://doi.org/10.1080/21594937.2017.1384307

Proyer, R. (2012). Examining playfulness in adults: testing correlates with personality, positive psychological functioning, goal aspirations, and multi-methodically assessed ingenuity. Psychological Test and Assessment Modeling, 54(2), 103-127. https://doi.org/10.5167/uzh-63532

Proyer, R. (2013). The well-being of playful adults: adult playfulness, subjective well-being, physical well-being, and the pursuit of enjoyable activities. European Journal of Human Research, 1(1), 84-98. https://doi.org/10.5167/uzh-78008

Proyer, R. (2014). To love and play: testing the association of adult playfulness with the relationship personality and relationship satisfaction. Current Psychology: A Journal of Diverse Perspectives and Diverse Psychological Issues, 33(4), 501-514. https://doi.org/10.1007/s12144-014-9225-6

Yu, P., Wu, J., Chen, H., \& Lin, T. (2007). Is playfulness a benefit to work? Empirical evidence of professionals in Taiwan. International Journal od Technology Management, 39, 412-419. https://doi.org/10.1504/IJTM. 2007.013503

Yue, D., Leung, L., \& Hiranandani, A. (2016). Adult playfulness, humor styles, and subjective happines. Psychological Reports, 119(3), 630-640. https://doi.org/10.1177/003329416662842

\section{OBRAZOVNI ASPEKTI PARTICIPACIJE ODRASLIH U IGROVNIM AKTIVNOSTIMA}

Pokazalo se da je razigranost u odraslom dobu neistraženo naučno pitanje. Verovatno razlog za to leži u ranijem nepriznavanju ovog pitanja kao posebne oblasti istraživanja, ali i prisutnog popularnog uverenja da su igrovne aktivnosti rezervisane samo za decu. Upravo zbog nedostatka inicijative ali $i$ koherentnih istraživanja koje uzimaju u razmatranje igrovne aktivnosti odraslih $i$ karakteristike razigranosti kao crte ličnosti ovo istraživanje moglo bi se smatrati prvim istraživanjem te vrste u Republici Srbiji. Cilj ovog istraživanja je da utvrdi percepcije odraslih o sopstvenoj razigranosti i dominantnim kognitivnim kvalitetima razigranosti. Za istraživanje razigranosti $i$ crti razigranosti svojstvenih kognitivnih karakteristika korišćena je APTS skala. Uzorak istraživanja obuhvatio je 1234 odrasla ispitanika starosti od 18 do iznad 60 godina iz gradskih i seoskih sredina na teritoriji Republike Srbije. Rezultati istraživanja pokazuju da ispitanici visoko procenjuju sve tri ispitivane subdimenzije crte razigranosti: motivisanost za zabavom, neinhibiranost i spontanost. Kao važan nalaz ovog istraživanja može se izdvojiti onaj koji ukazuje na karakteristike subdimenzije motivisanosti za zabavom kao dominirajuće.

Ključne reči: razigranost, odraslo doba, motivosanost za zabavom, neinhibiranost, spontanost 